Journal Clean WAS (JCleanWAS)

DOI : http://doi.org/10.26480/jcleanwas.01.2019.16.20

ZIBELINE INTERNATIONAL

ISSN: 2521-0912 (Print)

ISSN: 2521-0513 (Online)

CODEN: JCOLBF

REVIEW ARTICLE

\title{
PERCEPTION OF GOVERNMENT SERVANTS IN SHAH ALAM ON THE UTILIZATION OF FOOD WASTE AS A RESOURCE FOR BIOGAS PRODUCTION IN MALAYSIA
}

\author{
Alia Samsudin', Mohd Armi Abu Samah" ${ }^{2 *}$, Mohd Yusuff Ishak ${ }^{1}$ \\ ${ }^{1}$ Faculty of Environmental Studies, Universiti Putra Malaysia, 43400, UPM Serdang Selangor \\ ${ }^{2}$ Department of Chemistry, Kulliyyah of Science, International Islamic University Malaysia, Jalan Sultan Ahmad Shah, Bandar Indera Mahkota, 25200 \\ Kuantan Pahang, Malaysia \\ *Corresponding Author Email: marmi@iium.edu.my
}

This is an open access article distributed under the Creative Commons Attribution License, which permits unrestricted use, distribution, and reproduction in any medium, provided the original work is properly cited.

\section{ARTICLE DETAILS}

\section{Article History:}

Received 23 December 2018

Accepted 26 January 2019

Available online 12 March 2019

\section{ABSTRACT}

A survey was done to find out the perception towards the practice of using food waste as a source for biogas in Malaysia. The objectives of the study were to see the perception on this issue and also to analyze the relationship between the knowledge of the respondents regarding food waste and biogas, and their habits in handling food waste with their perception. The respondents for this survey were government servants working in Shah Alam. From the survey, it was found out that they have generally positive perception towards the idea of implementing the utilization of food waste generated daily as a source for the production of biogas. However, it was found out through this study that the respondents have very little knowledge regarding food waste and biogas in general. There are significant positive relationships seen between the knowledge and their habits in handling food waste with the perception of the respondents about this issue. This shows that the public needs to be more educated regarding this issue.

\section{KEYWORDS}

Food waste, biogas, anaerobic digestion, sustainable energy.

\section{INTRODUCTION}

\subsection{Solid waste in Malaysia}

The increasing amount of solid waste generated in Malaysia is a very worrying matter. The solid waste composition mainly consists of food waste. Instead of discarding these food wastes at landfills, recycling and utilizing them as a source for biogas is a more sustainable solution. Production of biogas could also be the best alternative that could replace our dependency on petroleum that is decreasing.

One of the most severe problems we are facing in Malaysia right now is the increase in waste produced daily. In the year 2012, Malaysia has generated 33,000 tons of solid waste daily which was supposedly projected to only happen in 2020. Rapid urbanization is the main reason for this to occur along with the advancement in living standards and population expansion [1]. The increase in the rate of waste generated exceeds the rate of the natural degradation process. About $95 \%$ of waste will end up at landfill sites for disposal. Only a small portion of the waste is treated. The other portions of waste are either sent for treatment at small incineration plants, diverted to recyclers or re-processors or is dumped illegally by irresponsible parties [2].

\subsection{Food waste}

Food waste is the remnants of food consumed and discarded. Every year, the type of waste that is the most highly generated is an organic waste, mainly a food waste. Especially in countries with lower income, organic waste accounts for about $64 \%$ of all the total waste [3]. The solid waste composition in Malaysia consists of a high concentration of organic waste and high moisture content and a bulk density of $200 \mathrm{~kg} / \mathrm{m} 3[4]$.

In 2010, the food waste in Kuala Lumpur constitutes for about $74 \%$ of the total waste in that area [5]. About 8000 tons of food waste which are equivalent to 8 million kilograms is disposed of daily in Malaysia [6]. Our habit of throwing food away without any guilt is equivalent to wasting all the climate change gasses generated in the production, processing, transportation and also storage of the food. If we stop the wastage of edible food, the amount of carbon dioxide that we could reduce is equivalent to taking an estimated 1 in 5 cars off the road.

The Urban Wellbeing, Housing and Local Government ministry have already announced that there will be a mandatory separation of waste implemented starting off 2015 [7]. The failure to separate organic from inorganic waste into the correct bins which are provided to each household would result in uncollected rubbish.

Food waste normally ends up in a landfill or is incinerated for possible recovery of energy. There is an untapped energy source that we throw into our bins daily which mostly ends up rotting in the landfill and releasing harmful air pollutants. We could be producing renewable electricity with our food waste instead of disposing of them. These food wastes can be transformed into a very useful resource for the production of biogas through various fermentation processes due to its organic- and nutrientrich composition [8].

If we could utilize food waste and recycle them as a source for biogas, this could help in reducing the hiking amount of wastes ending up in landfills. The challenges we are facing today are at closing existing landfills and also due to land scarcity in opening new landfills. Annually, household solid waste contributes to a very high amount in solid waste sources in Malaysia. It is very hard to require households to decrease their consumption rate and waste generation rate since we are so used to this lifestyle [9]. Furthermore, it is also to avoid the waste of energy that is invested in producing all those food in the first place. Using food waste to generate biogas can also help the food market as the prices of the required food products fluctuate to meet the demand for fuel [10].

\subsection{Biogas}

Biogas is a mix of gasses produced by the natural fermentation of wet biomass under the exclusion of oxygen which is anaerobic digestion or fermentation. It is actually a biodegradation process by bacteria under anaerobic conditions. Anaerobic digestion utilizes microorganisms that 
convert organic waste into a methane-rich biogas that can be combusted to generate electricity and heat or converted to biomethane. This technology is most suitable for food waste or wet organic wastes.

Other than carbon dioxide, sulfide, oxygen and water vapor, methane makes up the majority of the mix of gasses [11]. The percentage of methane depends on the biomass and the efficiency of the fermentation process. Some of the types of biomass that can be used for biogas production are an organic waste (food waste), plant materials, agricultural waste and also animal excrements. The other output from anaerobic digestion is biofertilizer. The digested from the fermentation process which is the fermentation residue or also known as activated sludge can be dried and used as fertilizer [12].

Figure 1 shows the process flow for biogas production. First, the food waste has to be separated from the solid waste. Then these food waste will be transported to a biogas plant where it will be fermented or undergo anaerobic digestion that will eventually produce biogas and also biofertilizer.

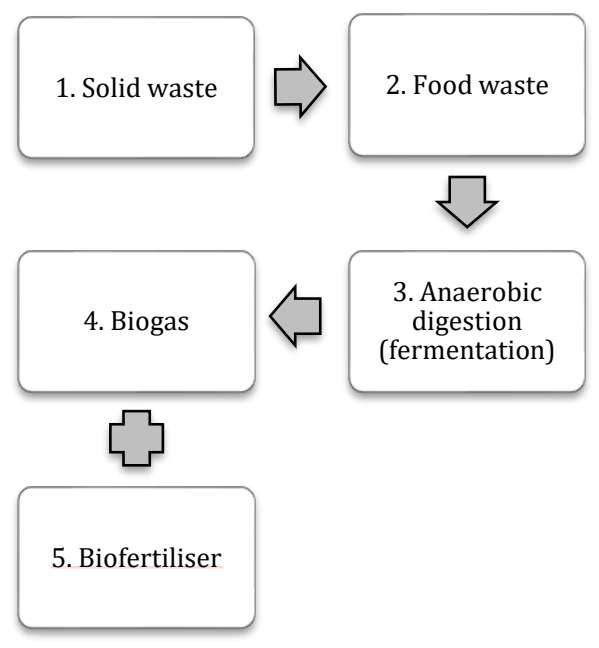

Figure 1: The process flow of biogas production.

Biogas, mainly methane can be used to generate electricity, for vehicle use and also as a raw material for the chemical industry. Other than that, methane can also replace liquefied petroleum gasses which are propane and butane used in cooking gas. Methane gas is also relatively clean burning, colourless, and odourless. So, this makes it a sustainable alternative to natural gas. Whether it is utilized by us or not, methane is still produced constantly by natural decomposition process. If not collected and released into the atmosphere, it becomes a major contributor to the global warming problem since it is a very harmful greenhouse gas. So, the utilization of biogas provides an excellent source of energy that is helpful to the environment.

\subsection{Biogas in Malaysia}

Biogas is produced using waste from the anaerobic decay of palm oil mill effluent (POME). POME is a good source of organic waste to generate methane gas by anaerobic digestion due to its high organic carbon content. Palm oil mills benefit from the methane gas production to generate electricity and also as fuel for their own boilers. In 2012, The Malaysian government introduced a renewable energy feed-in tariff to incentivize the conversion of waste into energy. This immediately put pressure on the palm oil producers to reduce waste from their production processes. In 2010, 12 mills in Malaysia have developed biogas plants [13]. The Malaysian Palm Oil Board targets to have biogas plants developed at 500 mills over the next 10 years. Out of these mills, 250 of them will target to supply electricity to the national grid by 2020 . It is estimated that a net profit of RM 3.8 million per year can be obtained in a palm oil mill with the processing capacity of 60 tons/ $\mathrm{hr}$ from electricity generation using biogas produced from POME treatment [14].

SP Multitech Renewable Energy Sdn.Bhd. in has developed a biogas plant where they utilize poultry wastes from chicken farms for the production of biogas. They use the biogas produced to generate electricity at those farms and has saved about RM 200 million a year on electricity cost since they started processing the wastes into biogas. These show that Malaysians are starting to realize the importance and the benefits of using biogas in daily life. However, for now, these are the only two sources of biogas production that are on a larger scale in Malaysia. There is not yet a company that utilizes food waste to produce biogas at a large scale in Malaysia.

\subsection{Biogas practices in other countries}

Recycling food waste may be relatively new in other parts of the world, but it is already a common practice for particularly in Europe. In Germany, residential food waste is mainly composed, with more than a quarter of it biodigester first. Most industrial and commercial food waste is broken down in biodigesters. In Europe, there are roughly 14,000 municipally operated biogas digesters, with nearly 9,000 in Germany alone. Elsewhere in Europe, composting is common, but anaerobic digestion is on the rise. It is growing quickly in the U.K. as well as Sweden, which last year announced their goal of recycling at least 50 percent of organic waste by 2018 either by composting or anaerobic digestion and 40 percent of the energy should be recovered. In Denmark, food industries are starting to reduce food waste from the production level by turning them into animal feed or used in the production of biogas as done by Arla Foods [15].

In Japan, food waste recycling is already a common practice. There is a law on food waste recycling that requires the public to segregate their waste at source. The sources for the methane fermentation are from food manufacture, food wholesale, the restaurant industry and also household food wastes. Several companies cooperate to collect and treat two million tons of food waste annually that is recycled into gas fuel by methane fermentation (MOEJ). The biogas produced is mainly utilized by gas turbines power generation within the facility. Another excess biogas is transferred or sold as boiler fuel to nearby factories. Fertilizers produced from the process are sold to the nearby vegetable farmers [16].

\subsection{Advantages of biogas}

The production of biogas is the cleanest and least toxic in the world since the biogas is produced by a natural process. It is just simply bacteria doing all the conversion of these food wastes into usable energy which is biogas. Also, through manufacturing of biogas, it reduces landfills. The process creates an odorless gas and a high nutrient fertilizer that is used on the farms. In a way, the production of this form of gas is better for the environment than not producing it. This energy form is clean burning and completely natural, so it has no adverse effects on the environment. It also reduces the amount of methane which is 20 times more potent than carbon dioxide released into the environment that is produced in landfills.

\subsection{Problem statement}

The amount of solid waste is increasing in Malaysia, especially food waste. The amount of food waste ending up in landfills can be reduced if we utilize them for the production of biogas. Besides, the issue of disposal and proper management of waste becomes the main concern in the country and worldwide [17].

Furthermore, unsustainable waste disposal is also an issue in Malaysia. Food wastes that are disposed at landfills without treatment will cause the formation of methane as the waste decomposes. The methane will be released into the air which is a very harmful greenhouse gas and also causes air pollution. Besides, the problems of waste water due to the population enlarge and rapid industrialization also requiring critical notice [18].

A decline in fossil fuel reserve is a worrying matter, especially for the future generation. We solely depend on the crude petroleum oil that will soon run out. The gas reserves are estimated to last another thirty 33 years, and oil reserves another 19 years [19]. The conversion of food waste into biogas is a good alternative fuel to compensate on the declining fossil fuel reserve.

Overall, the main problem is without proper management of solid waste especially food waste, it still can lead to pollution and affect human health. Perception of government servant is important to reflect the attitude towards waste management. Result of this study can be used as a first step to approach the government to take this matter seriously.

\subsection{Objectives}

The aim of this study is to see the perception of the respondents on the use of food waste for the production of biogas. The results of this study can be used to assist in the development of a policy to encourage the segregation of food waste for processing into biogas. The objectives of this study are as follows:

1. To evaluate respondents' perception towards the utilization of food waste as a source for biogas in Malaysia and also to see if there is a difference in the respondents' responses according to their age, income and education level 
2. To analyze the relationship between the knowledge of the respondents regarding food waste and biogas, and their habits in handling food waste with their perception

\section{METHODOLOGY}

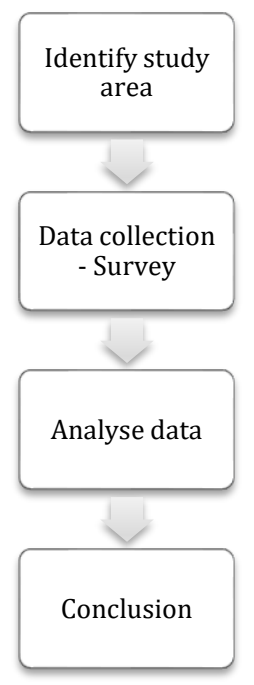

Figure 2: Framework for research methodology

Table 1: Number of questionnaires distributed at government agencies

\begin{tabular}{|l|l|}
\hline Government agency & No of questionnaires \\
\hline Jabatan Kerja Raya & 50 \\
\hline Pejabat Tanah dan Galian Selangor & 25 \\
\hline Lembaga Hasil Dalam Negeri & 25 \\
\hline Jabatan Alam Sekitar & 25 \\
\hline Jabatan Kesihatan Negeri Selangor & 25 \\
\hline Majlis Bandaraya Shah Alam & 25 \\
\hline $\begin{array}{l}\text { Jabatan Mineral dan Geosains Negeri } \\
\text { Selangor }\end{array}$ & 25 \\
\hline Jabatan Pertanian Pam & 25 \\
\hline $\begin{array}{l}\text { Suruhanjaya Perkhidamatan Awam } \\
\text { Negeri Selangor }\end{array}$ & 25 \\
\hline Jabatan Perangkaan & 25 \\
\hline Jabatan Penerangan & 25 \\
\hline
\end{tabular}

\subsection{Survey}

The target group for the study is government servants working in the Shah Alam area. This study is focused on this city because Shah Alam is the capital city of Selangor and this is where many government agencies are located. 11 government agencies in Shah Alam were selected randomly for the study. The sample size is 278 according to Krejcie and Morgan (1970). 300 sets of questionnaires were given out at government agencies around Shah Alam. 25 sets of questionnaires were distributed to each government agency except for JKR where 50 questionnaires were given out there because their office in Shah Alam has many staffs compared to the other agencies (Table 1).

Each survey contains 18 questions, excluding the demographic background. The respondents were required to answer two sections of the survey. The first section is about their demographic backgrounds such as age, gender, ethnicity, education background, and income. The second section consists of questions that are going to rate their perception towards this topic which the conversion of food waste into biogas is. This section is divided into three parts which are Knowledge, Habit, and Perception. The Knowledge part is to find out the respondents' knowledge regarding food waste and biogas in general. The Habit part is about their food waste handling habits. Lastly, the Perception part consists of questions that ask the respondents about their perception on the utilization of food waste as a source for biogas. There were 7 items in Knowledge, 3 in Habit and 8 items in the Perception part.

\subsection{Data Analysis}

The Statistical Package for Social Sciences (SPSS) Version 16 software was used to analyze the perception of the respondents. Independent T-test and One-Way ANOVA was used to see the difference in perception between the independent factors involved which are the age, education level, and income. The Pearson Correlation was done to determine the strength of the relationship between the knowledge with perception and also the habit of the respondents with their perception.

\section{RESULTS AND DISCUSSION}

Out of the 300 survey questions handed out, only 184 (61\%) sets were received and answered at the end of the study. Some of the surveys were not returned while most of the surveys that were returned but unanswered were because many staffs were out on field work. While the others did not give full cooperation as they said that they could not find time to fill the survey as they were busy. The numbers of respondents according to the government agencies are as shown in Table 2. The majority of the respondents were female $(70 \%)$ while the male respondents were only $28 \%$ of the total. The background of the respondents is summarized in Table 3.

The largest group are aged 25-34 (60\%) followed by 18-24 (16\%), 35-49 $(14 \%)$ and only $8 \%$ are more than 50 years old. Most of the respondents level of education is up to university level (53\%) while $33 \%$ only went to high school and $11 \%$ went to college. For the income, the largest group of respondents have a monthly income of RM 1,001-RM5,000 (7\%) while only $3 \%$ of them have an income of more than RM10,000. There were a few questionnaires where the respondents did not fill in the whole profile section and some left just the "Income" space blank.

Table 2: Number of respondents according to government agencies

\begin{tabular}{|l|l|}
\hline Government agency & Respondents \\
\hline Jabatan Kerja Raya & 40 \\
\hline Pejabat Tanah dan Galian Selangor & 10 \\
\hline Lembaga Hasil Dalam Negeri & 25 \\
\hline Jabatan Alam Sekitar & 15 \\
\hline Jabatan Kesihatan Negeri Selangor & 25 \\
\hline Majlis Bandaraya Shah Alam & 3 \\
\hline Jabatan Mineral dan Geosains Negeri Selangor & 4 \\
\hline Jabatan Pertanian & 12 \\
\hline Suruhanjaya Perkhidamatan Awam Negeri Selangor & 15 \\
\hline Jabatan Perangkaan & 17 \\
\hline Jabatan Penerangan & 18 \\
\hline Total & 184 \\
\hline
\end{tabular}

Table 3: Demographic background of respondents

\begin{tabular}{|c|c|c|c|c|c|}
\hline Background information & \multicolumn{5}{|c|}{ Respondents groups } \\
\hline \multirow{2}{*}{ Age } & $18-24$ & $25-34$ & \multicolumn{2}{|l|}{$35-49$} & $>50$ \\
\hline & $16 \%$ & $60 \%$ & \multicolumn{2}{|l|}{$14 \%$} & $8 \%$ \\
\hline \multirow{2}{*}{ Gender } & \multicolumn{2}{|l|}{ Male } & \multicolumn{3}{|c|}{ Female } \\
\hline & \multicolumn{2}{|l|}{$28 \%$} & \multicolumn{3}{|l|}{$70 \%$} \\
\hline \multirow{2}{*}{ Education background } & \multicolumn{2}{|l|}{ High school } & College & \multicolumn{2}{|l|}{ University } \\
\hline & \multicolumn{2}{|l|}{$33 \%$} & $11 \%$ & \multicolumn{2}{|l|}{$54 \%$} \\
\hline \multirow{2}{*}{ Income (RM) } & $<1,000$ & $1,001-5,000$ & \multicolumn{2}{|c|}{$5,001-10,000$} & $>10,000$ \\
\hline & $7 \%$ & $77 \%$ & $10 \%$ & & $3 \%$ \\
\hline
\end{tabular}




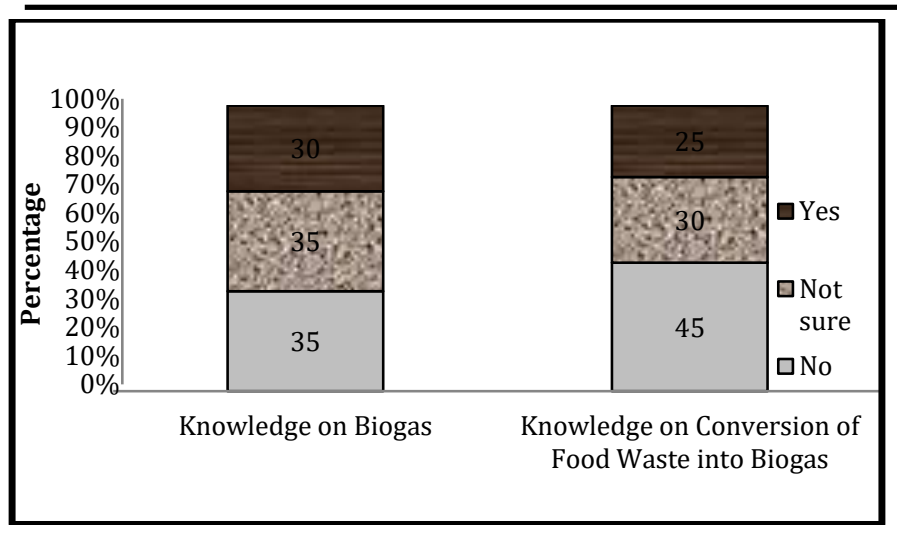

Figure 3: Respondents' knowledge on the issue

Figure 3 shows the knowledge of the respondents on the topic of this study. Most of them (75\%) answered that they have no knowledge at all or is not sure about what is biogas. The same goes for their knowledge on the conversion of food waste into biogas where (71\%) have no knowledge at all or is not sure about this. Only $25 \%$ knows what biogas is and $29 \%$ have the knowledge that food waste can be converted into biogas. Many might not know about biogas in general because there is not much exposure to this matter to the public either through education, reading materials or mass media. This lack of knowledge could become a barrier that causes the public to have a negative perception on the implementation of the utilization of food waste as a source for biogas in Malaysia.

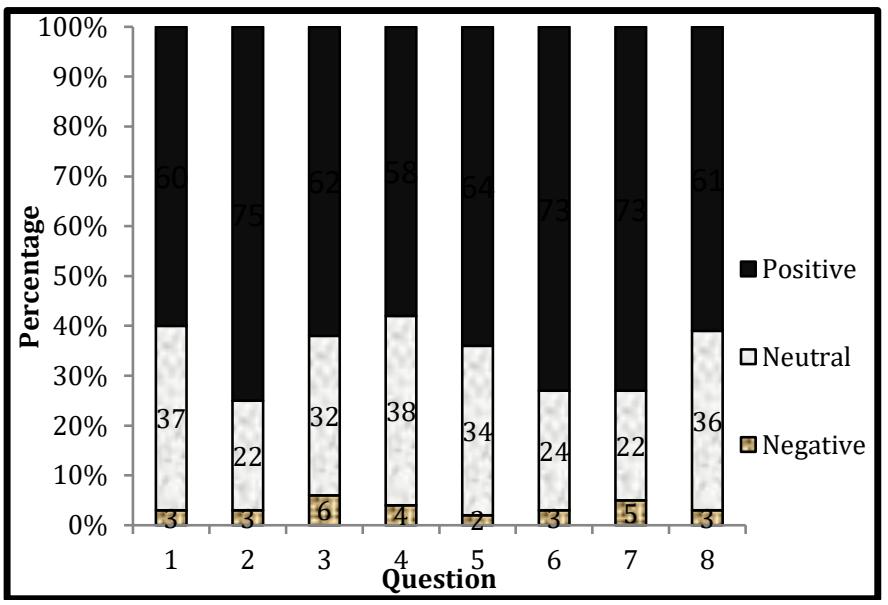

Figure 4: Respondents' perception on utilization of food waste as a source for biogas

Question 1: Do you feel that the usage of food waste as a source for biogas is good?

Question 2: Do you agree that all parties (government, the private sector, individuals, etc.) should participate in this effort for biogas production? Question 3: Would you agree if the government makes it compulsory to segregate food waste for this purpose of biogas production?

Question 4: Do you agree that the utilization of food waste as a source for biogas can cut cost for vehicle fuel?

Question 5: Do you feel that the utilization of food waste as a source for biogas can benefit consumers?

Question 6: Do you think that the utilization of food waste as a source for biogas can help save the environment?

Question 7: Do you think that the utilization of food waste as a source for biogas could help reduce the problem of increasing solid waste in Malaysia?

Question 8: Do you think that the utilization of food waste as a source for biogas is better for the replacement of natural gas (example: petroleum, methane, etc.

Figure 4 shows the perception of the respondents on the utilization of food waste as a source for biogas production in Malaysia. Most of the respondents have a positive perception on this issue. Negative responses were the highest (6\%) when asked whether they are willing to segregate their food waste from other wastes if the government makes it compulsory for the purpose of biogas production. While there were the most positive responses $(75 \%)$ when asked whether the respondents agree that everyone should participate in making this happen. The problem with us humans is that we want something that would benefit us but as long as it does not involve us actually having to do something for it to happen, hence the disagreements when asked about their willingness to segregate food waste at their homes. They might feel that having to separate their food wastes from source is tedious.

Table 4 shows the independent sample T-test to see the difference in perception in between the two genders. The result indicates that there is no significant difference between the male and female perception on the issue as $p=0.155$ at a significance level of $\alpha=0.05$.

Table 4: Independent sample t-test for comparing the perception between gender

\begin{tabular}{|l|l|l|l|l|l|}
\hline Variable & Gender & N & Mean & Standard Deviation & P value \\
\hline Perception & Male & 52 & 30.94 & 4.53 & 0.155 \\
\hline & Female & 129 & 29.64 & 5.94 & \\
\hline
\end{tabular}

Level of significance $(\mathrm{p}<0.05)$

One Way ANOVA analysis were done for comparing the perception with education level (Table 5), perception with income (Table 6) and also perception with age (Table 7). The results showed that there are no significant differences in the perception between these three variables. From the analysis, findings indicated that at $\alpha=0.05$ the $p$ values for the difference in perception are $p=0.221, p=0.790$ and $p=0.360$ for education level, income and age respectively. However, in reality, these factors do affect the future implementation of processing food waste to produce biogas in our country.

Table 5: One-way ANOVA for comparing perception with education level

\begin{tabular}{|l|l|l|l|l|l|}
\hline Education level & $\mathrm{N}$ & Mean & Standard Deviation & $\mathrm{F}$ & Sig. \\
\hline High school & 61 & 29.46 & 5.22 & 1.480 & 0.221 \\
\hline College & 21 & 28.24 & 7.69 & & \\
\hline University & 99 & 30.73 & 5.22 & & \\
\hline
\end{tabular}

Table 6: One-way ANOVA for comparing perception with income

\begin{tabular}{|l|l|l|l|l|l|}
\hline Income (RM) & N & Mean & Standard Deviation & F & Sig. \\
\hline$<1,000$ & 13 & 30.92 & 4.97 & 0.482 & 0.790 \\
\hline $1,001-5,000$ & 142 & 30.11 & 5.45 & & \\
\hline $5,001-10,000$ & 18 & 28.39 & 7.69 & & \\
\hline$>10,000$ & 6 & 31.33 & 3.44 & & \\
\hline
\end{tabular}

Table 7: One-way ANOVA for comparing perception with age

\begin{tabular}{|l|l|l|l|l|l|}
\hline Age & N & Mean & Standard Deviation & F & Sig. \\
\hline $18-24$ & 29 & 29.97 & 5.62 & 1.096 & 0.360 \\
\hline $25-39$ & 111 & 30.20 & 4.77 & & \\
\hline $40-49$ & 26 & 28.23 & 8.65 & & \\
\hline$>50$ & 15 & 31.80 & 4.13 & & \\
\hline
\end{tabular}

*Level of significance $\mathrm{p}<0.05$

Table 8: Pearson correlation test between perception with habit and knowledge

\begin{tabular}{|l|l|l|}
\hline Variable & Perception & $\begin{array}{l}\text { Correlation } \\
\text { coefficient }\end{array}$ \\
\hline Habit & $0.00^{* *}$ & 0.212 \\
\hline Knowledge & $0.004^{* *}$ & 0.289 \\
\hline
\end{tabular}

\section{${ }^{* *} \mathrm{p}<0.05$ (2-tailed)}

The Pearson correlation test (Table 8) showed that both the habit $(\mathrm{p}=$ $0.00)$ and knowledge $(p=0.004)$ have significant difference at $\alpha=0.05$. The correlation coefficient or $r$-value for habit and perception is 0.212 , while $r=0.289$ for knowledge and perception. The value of the correlation coefficient indicates the strength, with larger absolute values indicating stronger relationships. This means that both the strength of the correlation for perception with knowledge and habit are small since both the values are in between +0.1 to +0.29 . Respondents with more knowledge tend to have a more positive perception towards the utilization of food waste as the source for biogas and vice versa. The lack of 
knowledge regarding this matter drives these respondents into thinking that the utilization of biogas is something that might not benefit them that much since they are not aware of the advantages of biogas [20]

In a study done in Nigeria, $48 \%$ of the respondents were aware of biogas. Less than $50 \%$ of them were willing to adopt biogas as an alternative cooking fuel in replace of charcoal. This proves that having knowledge about the issue does influence the perception or the acceptance towards this idea. This is the same for habit where the respondents that have better habits in handling food waste at their homes have a more positive perception too. Since they have already practiced separating food waste at home, they would not mind having to do it for the purpose of biogas production in the future.

\section{CONCLUSION}

Energy security is one of the major concerns during development. The energy demand is predicted to increase by $4.7 \%$ annually where the electricity consumption having an annual growth rate of $8.1 \%$. It's indicated that demand for energy especially biogas is increasing.

The study shows that most of the public have a positive perception regarding the idea of converting food waste generated into biogas. There is also no significant difference in the perceptions of the respondents according to their age, income and education level. The correlation tests done shows that there are positive relationships between the perception of the respondents with their habit and knowledge.

Generally, the lack of knowledge is becoming a constraint for the public to accept this renewable energy source if we were to adopt it in the future. The public needs more enlightenment regarding biogas so that they are made aware of the environmentally friendly alternatives that are much more cost effective than fossil fuels at the same time. The school, media, family and friends play a major role in information dissemination and these channels can be used to ensure environmental issues are known to the general public.

The production of biogas from food waste sources could only be done if there are cooperation and participation from all parties including the government, private sectors, and individuals. Since the mandatory waste separation from the source will be implemented in 2015, the government should take this opportunity to direct the separated organic waste collected from households to biogas plants so that it could be processed into biogas. Once everyone is doing their part, it would be easier for us to apply this technology for the benefits of our future. The waste produced that is going to be discarded could be converted into valuable energy for all. We must also be reminded that biogas is a cleaner, safer and a more sustainable source of renewable energy compared to fossil fuels. Even though the cost of building a biogas plant might be expensive, it will still be far more profitable in return in so many aspects and boost Malaysia's economy as well.

\section{REFERENCES}

[1] Hoornweg, D., Bhada-Tata, P. 2012. What a waste: a global review of solid waste management. Urban development and local government unit, World Bank, Washington DC, USA, 2012.

[2] NSP. 2005. National Strategic Plan for solid waste management in Malaysia: Ministry of Housing and Local Government.

[3] Ismail, S.N.S., Manaf, L.A. The challenge of the future landfill: A case study of Malaysia, Journal of Toxicology and Environmental Health Sciences, 5(6), 86-96.
[4] Samah, M.A.A., Manaf, L.A.A., Ahsan, A., Sulaiman, W.N.A., Agamuthu, P. D'Silva, J.L. 2013. Household Solid Waste Composition in Balakong City Malaysia: Trend and Management, Polish Journal of Environmental Studies, 22(6), 1807-1816.

[5] Budhiarta, C.S., Basri, H. 2012. Current status of municipal solid waste generation in Malaysia, International Journal of Advanced Science Engineering Information Technology, (2), 16-21.

[6] JPSPN. National Solid Waste Management Department, Ministry of Human Wellbeing, Housing and Local Government http://www.kpkt.gov.my/ (accessed on 15th November 2014)

[7] The Malaysian Insider. Compulsory for Malaysians to separate rubbish from next year. http://www.themalaysianinsider.com/ (accessed on 25th November 2014]

[8] Kiran, E.U., Trzcinski, A.P., Ng, W.J., Liu, Y. 2014. Bioconversion of food waste to energy: A review, Fuel, (134), 389-399.

[9] Moh, Y.C., Manaf, L.A. 2014. Overview of household solid waste recycling policy status and challenges in Malaysia, Resources, Conservation, and Recycling, (82), 50-61.

[10] Gerlach, F., Grieb, B., Zerger, U. 2013. Sustainable biogas production: A handbook for organic farmers.

[11] AEBIOM. European Biomass Association. A Biogas Roadmap for Europe. http://www.aebiom.org (accessed on 2nd October 2014)

[12] MPOB. Malaysian Palm Oil Board. National Key Economic Areas. Chapter 9: Palm Oil. http://www.mpob.gov.my (accessed on 9th November 2014)

[13] Chin, M.J., Poh, P.E., Tey, B.T., Chan, E.S., Chin, K.L. 2013. Biogas from palm oil mill effluent (POME): Opportunities and challenges from Malaysia's perspective, Renewable and Sustainable Energy Reviews, (26), 717-726.

[14] Kosmo. Najis Jadi Tenaga Elektrik dan Baja by Adlan Jaafar. http://www.kosmo.com.my/ (accessed on 9th November 2014)

[15] Ushikubo, A. 2014. Recycling of Food Waste in Japan http://www.oecd.org/ (accessed on 4th October 2014

[16] Institution of Engineers Malaysia (IEM). 2008. Position paper on energy efficiency. IEM Position Paper on Energy Efficiency (PPEE), 4-45.

[17] Andres, M.T.J. 2016. Development of Biodegradable Plastic as Mango Fruit Bag, International Journal on Advanced Science, Engineering and Information Technology, 6(5), 799-803.

[18] Sutrisno, I., Wardani, A.K., Ratnawati, L. 2016. Isolation and Identification of A Lipid-Degrading Bacteria from Fish (Sardinella longiceps) Canning Wastewater, International Journal on Advanced Science, Engineering and Information Technology, 6(4), 441-446.

[19] Abdulkarim, I.A., Lambu, I.B., Ahmed B.Y., Sheriff, F.M. 2013. People's Awareness and Attitude on Biogas as an Alternative Domestic Energy in Urban Kano, Academic Research International, 4(6), 625-635.

[20] Keong, C.Y. 2005. Energy demand, economic growth and energy efficiency-the Bakun dam-induced sustainable energy policy revisited Energy Policy, 33, 679-689, 2005.

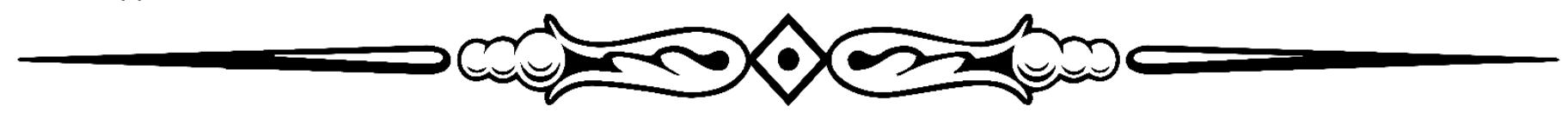

